\title{
Fine Needle Aspiration Cytology Study of Soft Tissue Tumours: A Study of 140 Cases
}

\author{
Anand Kanasagara* and Krishna D Vaghani \\ Dept. of pathology, GMERS medical college, himmatnagar, Gujarat, India
}

\begin{abstract}
Background: The diagnosis of soft tissue tumours has always been difficult and controversial. The use of fine needle aspiration cytology ( FNAC ) instead of incisional biopsy for the diagnosis of soft tissue tumours was first reported in 1919 and since then has become a very popular cytodiagnostic procedure. Our aim is to study type of soft tissue tumors, age, sex and site distribution, incidence of benign and malignant lesions, to know role of FNAC and its efficacy in diagnosis of soft tissue tumors\& compare our results with previous published studies.

Methods: Total 140 cases of soft tissue tumors were studied prospectively from september 2013 to november 2015, out of them 31 cases were followed up for cytology-histopathology comparison.

Results: Most common site of soft tissue tumors was upper extremities, $91.5 \%$ of all the lesions were benign \&most common tumor was lipoma.

Conclusion: FNAC is a very useful tool for diagnosis of soft tissue tumors, in our study we found that FNAC was $100 \%$ accurate in diagnosing malignant tumors, $96 \%$ accurate in diagnosing benign soft tissue tumors\& $90.3 \%$ efficient in identifying whether a tumor is benign or malignant.
\end{abstract}

Keywords: FNAC, Soft Tissuetumors, Cytology-Histopathology Comparison.

\section{Introduction}

Soft tissue tumours are defined as mesenchymal proliferations that occur in the extraskeletal, nonepithelial tissues of the body, excluding the viscera, coverings of the brain, and lymphoreticular system. ${ }^{[1]}$ The use of fine needle aspiration instead of incisional biopsy for the diagnosis of soft tissue tumours was first reported in 1919 and since then has become a very popular cytodiagnostic procedure. [2]

This study was done to know the frequency of age, sex and site distribution of soft tissue tumors, to find out relative incidence of benign and malignant tumors \& to do cytology - histopathology comparision of soft tissue tumors to evaluate the efficacy of FNAC.

\section{Material and Methods}

The present study was undertaken to study the efficacy of fine needle aspiration cytology in diagnosis of soft tissue tumors as well as histopathological comparision of tumors in the department of Pathology, Govt. Medical College and Surat.

Total 140 cases were studied, all of them are of prospective study from September 2013 to November 2015. A clear explanation of procedure was given to patient to get his/ her consent and cooperation. Fine needle aspiration was performed with 22 gauge needle. Slides were stained by Haematoxylin \& Eosin, May Grunwald Giemsa and Papanicolaou stain. Special stain was also done in required cases. Out of 140 cases, 31 cases were followed up for histopathology and for cyto-histo comparision.

\section{Results}

We compared the cytological diagnosis with the final diagnosis as assessed by histological examination. There were 81 males and 59 females and their age ranged from less than 1 year to 78 years. In present study soft tissue tumors were more common in male $(57.9 \%)$ than female $(42.1 \%)$ and male female ratio was 1.4:1.

In present study total 140 cases were studied. Maximum number of cases were in age range of 21 to $30(26.5 \%)$ (Table 1). Second most common age group was 31-40 years and minimum number of cases were in range of age of less than 1 year $(0.7 \%)$. The age range of patients was less than 1 year to 78 years. Crowding of soft tissue tumor cases were in third to fifth decades of life which were around $65.8 \%$ of cases.

In present study most common site of soft tissue tumors was upper extremity (35\%) followed by head and neck area $(23.60 \%)$ (Table 2). 3rd most common site was lower extremity. Overall soft tissue tumors are very common in 
extremities accounting for $45.7 \%$ cases. Least common sites were chest and abdomen.

In present study benign soft tissue tumors were $91.5 \%$, malignant were $7.1 \%$ and $1.4 \%$ were inconclusive.

In present study out of 140 cases, 128 cases were benign. Most common benign tumor was lipoma (52.3\%)(Table 3). Second most common was ganglion (10.9\%). In $14.8 \%$ cases broad diagnosis were given as Benign spindle cell tumor. Least Common tumor was lipofibroma and only one case was found.

In present study total 10 cases of malignant soft tissue tumors were found, out of which most common was pleomorphic sarcoma $(40 \%)($ Table 4$)$. In present study most common type of tumor was adipocytic (48.6\%) tumors. 3rd most common type of tumor was myxoidtumor (10\%). On cytology in $17.1 \%$ cases specific diagnosis was not given.
In present study out of 140 cases, we have done follow up in 31 cases about histopathology result to know the efficacy of FNAC in stamping a tumor as benign or malignant. Out of 31 cases 25 cases were diagnosed as benign tumors, 4 cases were diagnosed as malignant \& 2 cases were inconclusive on FNAC probably due to inadequate material or necrosis. Out of 25 benign cases 1 case turned out to be malignant in histopathology, so according to our study specificity of FNAC in diagnosing a benign tumor is $96 \%$. All the 4 malignant lesions were found malignant on histopathology also, so specificity of FNAC in diagnosing a malignant tumor is $100 \%$ according to our study. Out of the 2 inconclusive results on FNAC, one found benign and other found malignant in histopathology. Ovarall in 28 out of 31 cases FNAC was able to correctly stamp a tumor as benign or malignant, so efficacy of FNAC in identifying a tumor as benign or malignant is $90.3 \%$ according to our study. (Table 5).

Table (1) : Distribution of cases according to age.

\begin{tabular}{|c|c|c|}
\hline Age group (In years ) & No. of cases & Percentage \% \\
\hline$<1$ & 1 & 0.7 \\
\hline $1-10$ & 6 & 4.3 \\
\hline $11-20$ & 13 & 9.3 \\
\hline $21-30$ & 37 & 26.5 \\
\hline $31-40$ & 30 & 21.4 \\
\hline $41-50$ & 25 & 17.9 \\
\hline $51-60$ & 15 & 10.7 \\
\hline $61-70$ & 10 & 7.1 \\
\hline $71-80$ & 3 & 2.1 \\
\hline Total & 140 & $100 \%$ \\
\hline
\end{tabular}

Table (2): Distribution Of Cases According To Location Of Tumor.

\begin{tabular}{|c|c|c|}
\hline Location & No. of cases & Percentage \% \\
\hline Head \& Neck & 33 & 23.6 \\
\hline Upper extremities and axilla & 49 & 35.0 \\
\hline Lower extremities and inguinal region & 29 & 20.7 \\
\hline Chest & 8 & 5.7 \\
\hline Back & 11 & 7.9 \\
\hline Abdomen and perineum & 8 & 5.7 \\
\hline Multiple sites & 2 & 1.4 \\
\hline Total & 140 & $100 \%$ \\
\hline
\end{tabular}


Table (3) : Spectrum Of Benign Tumors On Cytology.

\begin{tabular}{|c|c|c|}
\hline Diagnosis & No. of cases & Percentage $\%$ \\
\hline Lipoma & 67 & 52.3 \\
\hline Benign fibrous Histiocytoma & 8 & 6.3 \\
\hline Giant cell tumor of tendon sheath & 9 & 7 \\
\hline Fibromatosis & 2 & 1.6 \\
\hline Ganglion & 14 & 6.3 \\
\hline Spindle cell tumor - neural origin & 8 & 14.8 \\
\hline Spindle cells tumor - Benign & 19 & 0.8 \\
\hline Lipofibroma & 1 & $\mathbf{1 0 0} \%$ \\
\hline Total & 128 & \\
\hline
\end{tabular}

Table (4) : Spectrum Of Malignant Tumors On Cytology.

\begin{tabular}{|c|c|c|}
\hline Diagnosis & No. of cases & Percentage $\%$ \\
\hline Atypical lipomatoustumor & 1 & 30 \\
\hline Ewing's Sarcoma & 3 & 40 \\
\hline Pleomorphic Sarcoma & 4 & 10 \\
\hline Low grade sarcoma & 1 & 10 \\
\hline Sarcoma - neural origin & 1 & $\mathbf{1 0 0} \%$ \\
\hline Total & $\mathbf{1 0}$ & \\
\hline
\end{tabular}

Table (5) : Cytology - Histopathology Comparision Study ( 31 Cases ).

\begin{tabular}{|c|c|c|}
\hline FNAC Diagnosis & Histopathology Diagnosis & No. of case \\
\hline Benign & Benign & 1 \\
\hline Benign & Malignant & 4 \\
\hline Malignant & Malignant & 1 \\
\hline Inconclusive & Benign & 1 \\
\hline Inconclusive & Malignant & 31 \\
\hline Total & & \\
\hline
\end{tabular}

(Note: As we have done only comparison, we did not use any statistical correlation test)

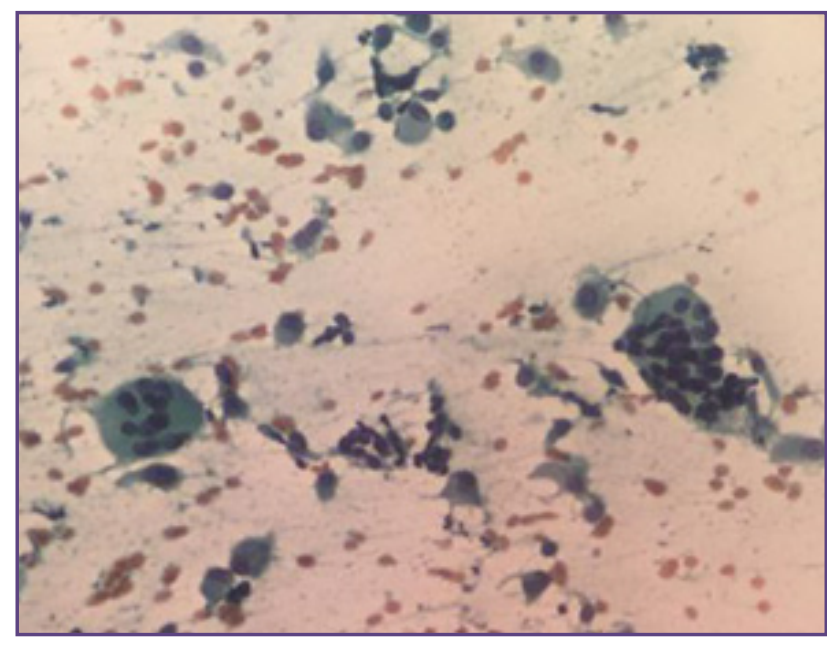

Fig. (1) : Giant Cell Tumour of Tendon Sheath, PAP Stain (40x).

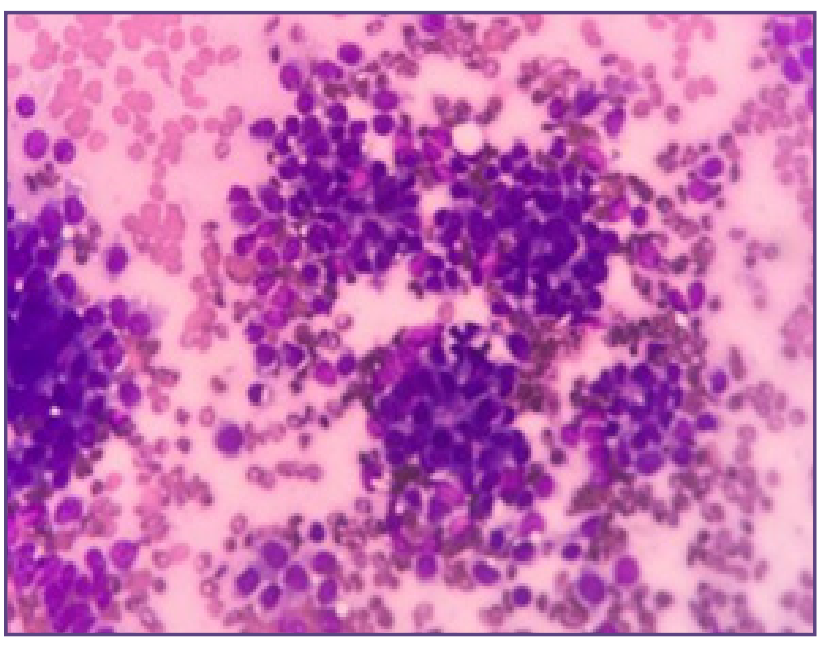

Fig. (2) : Ewing's Sarcoma, MGG Stain (40x). 


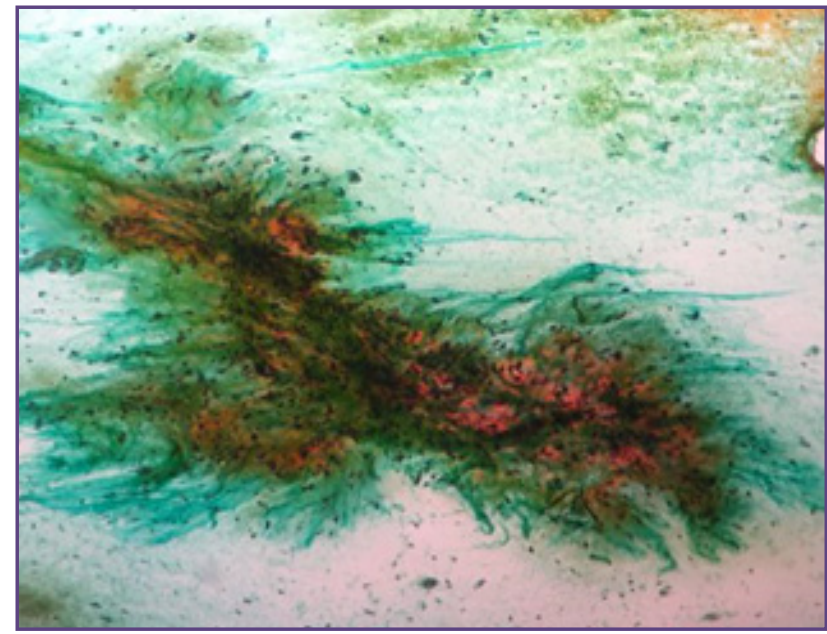

Fig (3) : Benign Fibrous Histiocytoma, PAP Stain (10x).

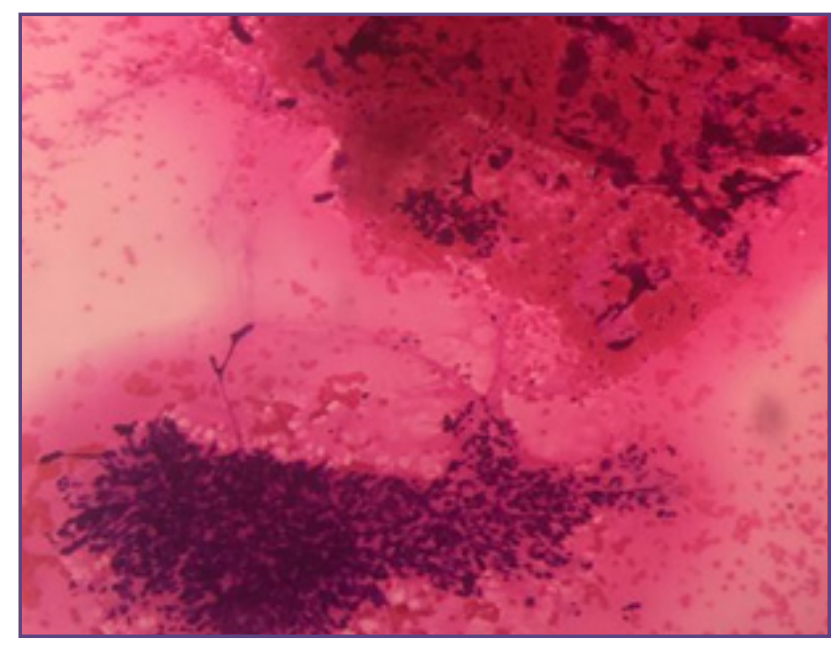

Fig. (5) : High Grade Sarcoma, H\&E stain (10x).

\section{Discussion}

In present study benign soft tissue tumors were most common in third decade (21-30 years) which is comparable to studies done by Hasan et al, Rekhi et al \& Choukimath M. et al, but it is not comparable to study done by Premila $\mathrm{J}$. et al probably due to difference in sample size.( Table 6) In present study malignant soft tissue tumors were most common in fifth decade (41-50)years, which is comparable to studies done by Chatura et al and Priyanka B. et al \& not comparable to other studies may be due to small number of malignant tumors to compare with. ( Table -6$)$

In present study male to female ratio was $1.4: 1$ which is almost comparable with other studies except studies done by Hirachand S. et al \& Hasan et al (Table 7).

In present study most common site of tumors was upper extremity and axilla which is comparable with studies done

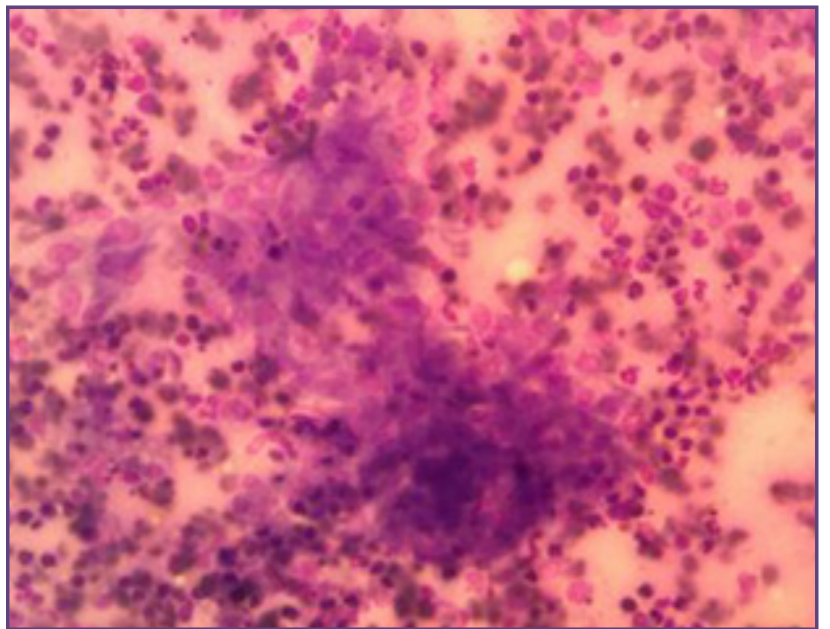

Fig. (4) : Malignant Peripheral Nerve Sheath Tumor, MGG Stain (40x).

by Tailor HJ et al, Hasan et al and Premila J. et al \& not comparable with study of Rasool $\mathrm{Z}$. et al probably due to small sample size. (Table 8).

In present study $91.5 \%$ cases were benign which is comparable with almost all other studies clearly showing that benign soft tissue tumors are far more common than the malignant ones (Table 9).

In present study most common type of tumor was adipocytic that is comparable with almost all the studies showing that lipoma is probably the most common soft tissue tumor (Table 10).

\section{Summary}

In Present study most common age group was 21-30 years. Least common age group was less than 1 year which was a case of fibromatosis colli. Benign tumors were most common in age group of 21-30 years and malignant tumors were most common in age group of $41-50$ years. Male to Female ratio was $1.4: 1$. In present study most common site of soft tissue tumor was upper extremity \& axilla(35\%) followed by head and neck area $(23.60 \%)$.

In present study $91.5 \%$ were benign soft tissue tumors, $7.1 \%$ were malignant and $1.4 \%$ were inconclusive. Most common cytomorphological pattern was lipomatous pattern $(47.9 \%)$ and second most common was spindle cell pattern $(35.0 \%)$. In present study most common type of tumor was adipocytic (49\%).

Most common benign tumor was lipoma (52.3\%). Second most common was ganglion (10.9\%). Most common malignant tumor was pleomorphic sarcoma.

In present study efficacy of FNAC to give whether the tumor is benign or malignant is $90.3 \%$.. On FNAC 4 cases 
Table (6): Comparision of most common age group.

\begin{tabular}{|c|c|c|}
\hline Authors & \multicolumn{2}{|c|}{ Most common age group } \\
\hline Hasan et al $(2012)^{(3)}(136$ cases $)$ & $21-30$ & $11-20$ \\
\hline Premila J. et al $(2014)^{(4)}(370$ cases $)$ & $61-70$ & $61-70$ \\
\hline Priyanka B. et al $(2014)^{(5)}(150$ cases $)$ & $31-40$ & $41-50$ \\
\hline Tailor HJ et al $(2013)^{(6)}(140$ cases $)$ & $31-40$ & $61-70$ \\
\hline Rekhi et al $(2007)^{(7)}(127$ cases $)$ & $21-30$ & $61-70$ \\
\hline Choukimath M. et al $(2012)^{(8)}(200$ cases $)$ & $21-30$ & $21-30$ \\
\hline Chatura et al $(2015)^{(9)}(27$ cases $)$ & $31-40$ & $41-50$ \\
\hline Present study $(2015)$ & $21-30$ & $41-50$ \\
\hline
\end{tabular}

Table (7) :Comparision Of Gender Distribution.

\begin{tabular}{|c|c|}
\hline Authors & Male : Female ratio \\
\hline Hasan et al $(2012)^{(3)}$ & $1.9: 1$ \\
\hline Premila J. et al $(2014)^{(4)}$ & $1.3: 1$ \\
\hline Tailor HJ et al $(2013)^{(6)}$ & $1.3: 1$ \\
\hline Priyanka B. et al $(2014)^{(5)}$ & $1.2: 1$ \\
\hline Choukimath M. et al $(2012)^{(8)}$ & $1.1: 1$ \\
\hline Hirachand s. et al $(2015)^{(10)}(50$ cases) & $1: 1$ \\
\hline Chatura et al $(2015)^{(9)}$ & $1.3: 1$ \\
\hline Present study $(2015)$ & $1.4: 1$ \\
\hline
\end{tabular}

Table (8) :Comparision According To Location Of Tumor.

\begin{tabular}{|c|c|c|c|c|c|c|}
\hline Site of tumor & $\begin{array}{l}\text { Hasan et } \\
\text { al }(2012)^{(3)}\end{array}$ & $\begin{array}{l}\text { Premila J. et } \\
\text { al }(2014)^{(4)}\end{array}$ & $\begin{array}{c}\text { Tailor HJ et al } \\
(2013)^{(6)}\end{array}$ & $\begin{array}{l}\text { Choukimath } \\
\text { M. et al } \\
(2012)^{(8)}\end{array}$ & $\begin{array}{c}\text { Rasool Z. et al } \\
(201)^{(11)}(100 \\
\text { cases) }\end{array}$ & $\begin{array}{l}\text { Present study } \\
\text { (2015) }\end{array}$ \\
\hline $\begin{array}{l}\text { Lower extremity \& } \\
\text { Inguinal region }\end{array}$ & $21.3 \%$ & $13.5 \%$ & $12.1 \%$ & $18 \%$ & $15 \%$ & $20.7 \%$ \\
\hline Upper extremity \& axilla & $28.6 \%$ & $27.2 \%$ & $32.8 \%$ & $21 \%$ & $16 \%$ & $35 \%$ \\
\hline Head \& neck & $13.9 \%$ & $30.8 \%$ & $22.8 \%$ & $14 \%$ & $34 \%$ & $23.5 \%$ \\
\hline Back & $14.3 \%$ & $17.5 \%$ & $14.2 \%$ & $10 \%$ & $12 \%$ & $7.8 \%$ \\
\hline Chest & $7.3 \%$ & $4.3 \%$ & $10 \%$ & $11 \%$ & $6 \%$ & $5.7 \%$ \\
\hline Abdomen \& Perineum & $11.7 \%$ & $5.4 \%$ & $2.4 \%$ & $6 \%$ & $14 \%$ & $5.71 \%$ \\
\hline Retroperitonium & -- & -- & -- & $3 \%$ & -- & -- \\
\hline Multiple sites & $2.2 \%$ & $1 \%$ & $1.4 \%$ & $14 \%$ & $3 \%$ & $1.4 \%$ \\
\hline Total & 136 & 370 & 140 & 200 & 100 & 140 \\
\hline
\end{tabular}


Table (9): Comparision Of Benign Vs Malignant Tumor.

\begin{tabular}{|c|c|c|c|c|c|c|c|}
\hline & $\begin{array}{l}\text { Hasan et al } \\
\begin{array}{c}(2012)^{(3)} \\
(\%)\end{array}\end{array}$ & $\begin{array}{c}\text { Premila J. } \\
\text { et al }(2014) \\
\quad{ }^{(4)}(\%)\end{array}$ & $\begin{array}{l}\text { Priyanka B. } \\
\text { et al }(2014) \\
(5)(\%)\end{array}$ & $\begin{array}{l}\text { Hemalatha A. } \\
\text { Et al }(2013)^{(12)} \\
(\%)(113 \text { cases })\end{array}$ & $\begin{array}{c}\text { Tailor HJ } \\
\text { et al }(2013) \\
{ }_{(6)}(\%)\end{array}$ & $\begin{array}{c}\text { Choukimath } \\
\text { M. et al } \\
(2012)^{(8)}(\%)\end{array}$ & $\begin{array}{l}\text { Present } \\
\text { study } \\
(2015)(\%)\end{array}$ \\
\hline Benign & 80.9 & 90.5 & 95.4 & 78.8 & 93.6 & 76 & 91.5 \\
\hline Malignant & 19.1 & 9.5 & 3.3 & 4.4 & 6.4 & 16 & 7.1 \\
\hline $\begin{array}{l}\text { Borderline / } \\
\text { Suspicious }\end{array}$ & - & - & 1.3 & 16.8 & - & - & - \\
\hline Inconclusive & - & - & - & - & - & 8 & 1.4 \\
\hline $\begin{array}{c}\text { Total No of } \\
\text { cases }\end{array}$ & 136 & 370 & 150 & 113 & 140 & 200 & 140 \\
\hline
\end{tabular}

Table (10) :Comparision Of Type Of Tumor.

\begin{tabular}{|c|c|c|c|c|c|}
\hline Type of tumor & $\begin{array}{l}\text { Premila J. et al } \\
\qquad(2014)^{(4)} \\
(\%)\end{array}$ & $\begin{array}{l}\text { Tailor HJ et al } \\
\qquad \begin{array}{c}(2013)^{(6)} \\
(\%)\end{array}\end{array}$ & $\begin{array}{c}\text { Roy S. et al } \\
(2007)^{(13)} \\
(\%)(105 \text { cases })\end{array}$ & $\begin{array}{c}\text { Hirachand s. et } \\
\text { al }(2015)^{(10)} \\
(\%)\end{array}$ & $\begin{array}{l}\text { Present study } \\
\text { (2015) (\%) }\end{array}$ \\
\hline Adipocytic & 50.3 & 75 & 25.7 & 38 & 48.6 \\
\hline Fibrous & 3 & 0.7 & 4.8 & 4 & 2.1 \\
\hline Fibrohistiocytic & 3.2 & 2.9 & 9.5 & 6 & 12.1 \\
\hline Neural & 19.8 & 4.3 & 8.6 & 18 & 6.4 \\
\hline Myxoid & -- & 2.9 & 8.6 & -- & 10 \\
\hline Vascular & 20 & -- & 5.7 & -- & -- \\
\hline Neuroectodermaltumor & 0.8 & 5.8 & 3.8 & -- & 2.1 \\
\hline Not specified & 3 & 8.6 & 26.7 & 26 & 17.1 \\
\hline Inconclusive & -- & -- & 6.7 & 8 & 1.4 \\
\hline Total no of cases & 370 & 140 & 105 & 50 & 140 \\
\hline
\end{tabular}

were diagnosed as malignant tumors and on histopathology all cases were found malignant, so according to our study if any tumor is found malignant in FNAC, it is $100 \%$ accurate. On FNAC 25 cases were diagnosed as benign tumors and only one case turned out to be malignant on histopathology, so according to our study if any tumor is found benign in FNAC, it is $96 \%$ accurate.

\section{Conclusion}

FNAC is a very useful tool for diagnosis of soft tissue tumors, in our study we found that FNAC was $100 \%$ accurate in diagnosing malignant tumors, 96\% accurate in diagnosing benign soft tissue tumors \& $90.3 \%$ efficient in identifying whether a tumor is benign or malignant.

Percutaneous fine needle aspiration cytology can be used for initial diagnosis of soft tissue tumors because it is simple, outpatient, rapid, safe, cost effective and nontraumatic procedure which offers sufficient tissue material and permits immediate operative or radiation therapy without lapse of time necessary for wound healing.

\section{References}

1. A. E. Rosenberg, -Bones, joints, and soft-tissue tumors editors,\| in Robbin's and Cotran Pathologic Basis of Disease, V. Kumar, A.K.Abbas,N. Fausto, and J. C.Aster, Eds., pp. 235-249, Saunders,Philadelphia, Pa, USA, 8th edition, 2010.

2. JaseemHasan, S. Shamshad Ahmad, KafilAkhtar .Percutaneous needle biopsy in the diagnosis of soft tissue tumors - A potent tool in underdeveloped countries. Journal of Medical Laboratory and Diagnosis November, 2012 ;Vol. 3(2), pp. 16-22.

3. JaseemHasan, S. Shamshad Ahmad, KafilAkhtar .Percutaneous needle biopsy in the diagnosis of soft tissue tumors - A potent tool in underdeveloped countries. Journal of Medical Laboratory and Diagnosis November, 2012 ; Vol. 3(2), pp. 16-22,

4. Premila Jain, ArchanaShrivastava, Reeni Malik. Clinicomorphological Assessment of Soft Tissue Tumors. Sch. J. App. Med. Sci., 2014; 2(2D):886-890

5. Priyanka Bhatia Soni, Anand Kumar Verma, Raj Kumar Chandoke, and Jitendra Singh Nigam. A Prospective Study 
of Soft Tissue Tumors - Histocytopathology Correlation. Pathology Research International, 2014, Vol. 5(1). Hemali J. Tailor, Vasudha M. Bhagat, Kumar Bhargav R. Kaptan, Sonal L. Italiya. Diagnostic accuracy of fine needle aspiration cytology in soft tissue tumorsInt J Res Med Sci. 2013 Nov;1(4):443-447

6. Bharat Rekhi ,Biru D Gorad1, Anagha C Kakade2 and RF Chinoy. Scope of FNAC in the diagnosis of soft tissue tumors-A study from a tertiary cancer referral center in India.CytoJournal 2007;4: 1-10

7. Choukimath M Sharanabasav, Rangappa P K. Fine needle aspiration cytology of soft tissue tumors with special emphasis on grading of spindle cell sarcomas. Internationational journal of applied biology and pharmaceutical technology. April 2012; 247-60

8. K. R. Chatura, AkshiKatyal, S. S. Hiremath. Fine-needle aspiration cytology in soft tissue tumors: How far did we go??.Journal of Advanced Clinical \& Research Insights
(2015),2: 107-111

9. Hirachand S, Lakhey M, Singha AK, Devkota S, Fine needle aspiration of soft tissue tumours. Kathmandu University Medical Journal (2007), Vol. 5, No. 3, Issue 19: 374-377

10. RasoolZubaida, Bhat M, SamoonNuzhat, Baba Khalil. Utility of Fine Needle Aspiration Cytology in Diagnosis of Soft Tissue Lesions with Histopathological Correlation. Global journal of medicine and public health. 2013; Vol. 2, issue 2: 1- 7

11. Hemalatha, A. L., Umarani. M. K., Asha. U. and NishthaBatra.Fine Needle Aspiration Cytology as a Primary Diagnostic Modality in Evaluation of Mesenchymal Lesions. Advances in Cancer Research \& Treatment. Vol. 2013;1-8

12. Roy S, Manna AK, Pathak S, Guha D. Evaluation of Fine Needle Aspiration Cytology and Its Correlation with Histopathological Findings in Soft Tissue Tumours. Journal of Cytology 2007; 24 (1) : 37-40

*Corresponding author:

Dr Anand Kanasagara, Dept. of pathology, GMERS medical college, himmatnagar, Gujarat, India

Email: spl.naroda@gmail.com

Financial or other Competing Interests: None. 